\title{
AN EXAMINATION OF SARIKAMIS DESTINATION COMPETITIVENESS FROM THE LUGE ATHLETES' PERSPECTIVE: THE RELATIONSHIP BETWEEN TOURISM EXPERIENCE AND PERCEIVED DESTINATION COMPETITIVENESS
}

\author{
Mikail Kara* \& Sinem Kunt**
}

\begin{abstract}
The purpose of this research is to examine the competitiveness of Sarkamı destination from the perspectives of the licensed luge athletes participating in 2019 Interclub Natural Luge Turkey Championship competition. The research also intends to reveal the relationship between perceived destination competitiveness and tourism experience. Two research questions were addressed in this research. The first question was to examine to what extent the competitiveness of Sarikamis destination from the luge athletes' perspective. The second question was to reveal the relationship between the tourism experience and perceived destination competitiveness. The Luge athletes have the opportunity to get experience in a wide range of ski centers at national or international area. Therefore, the perspectives of experienced athletes are important in determining the competitive advantage elements of Sarikamis destination. The data collection of this research is the questionnaire conducted with the luge athletes participating in the competition $(n=191)$. The results indicated Sarikamis destination competitiveness from the luge athletes' perspective that the highest three mean scores were "The destination's overall favorable image in the world community, "The destination's commitment to promoting a positive image" and this was following: "The destination's commitment to providing a safe and secure environment. The research also revealed that the luge athletes' perception of destination competitiveness and tourism experience in the destination do positively relate to each other. The research provided managerial implications to Sarıkamış destination managers and marketers based on the research findings. Effective image studies should be conducted in order to ensure that the Sarıkamış Cıbltepe Ski Center can compete with other destinations internationally. In Sarıkamış Cıbltepe Ski Center, high-quality health services should be provided against the possible injuries and accidents of the athletes.
\end{abstract}

Key words: Destination Competitiveness, Tourism Experience, Sports Tourism, Luge Athletes, Sarıkamış.

\section{UMA ANÁLISE DA COMPETITIVIDADE DO DESTINO SARIKAMIŞ NA PERSPECTIVA DOS ATLETAS DE LUGE: A RELAÇÃO ENTRE A EXPERIÊNCIA DO TURISMO E A COMPETITIVIDADE PERCEBIDA DO DESTINO}

Resumo

O objetivo desta pesquisa é examinar a competitividade do destino Sarıkamış a partir da perspectiva dos atletas de Luge [trenó] participantes da competição do Campeonato Interclubes Natural Luge Turquia de 2019. A pesquisa também visa revelar a relação entre a percepção da competitividade do destino e a experiência turística. Duas questões de pesquisa foram abordadas nesta pesquisa. A primeira questão era examinar até que ponto a competitividade do destino Sarikamis a partir da perspectiva dos atletas de Luge. A segunda questão era revelar a relação entre a experiência turística e a percepção da competitividade do destino. Os atletas de Luge têm a oportunidade de ganhar experiência em uma ampla gama de estações de esqui na área nacional ou internacional. Portanto, as perspectivas dos atletas experientes são importantes para determinar os elementos de vantagem competitiva do destino Sarikamis. A coleta de dados desta pesquisa é o questionário realizado com os atletas de Luge que participam da competição $(n=191)$. Os resultados indicaram a competitividade do destino Sarikamis a partir da perspectiva dos atletas de calibre que as três pontuações médias mais altas foram "A imagem geral favorável do destino na comunidade global", "o compromisso do destino em promover uma imagem positiva" e daí se segue: "o compromisso do destino em proporcionar um ambiente seguro e protegido". A pesquisa também revelou que a percepção dos atletas sobre a competitividade do destino e a experiência turística do destino estão positivamente relacionadas umas com as outras. A pesquisa forneceu implicações gerenciais para os gerentes de destino e marqueteiros do Sarıkamış com base nos resultados da pesquisa. Estudos de imagem eficazes devem ser conduzidos para garantir que o Sarıkamış Cıbıltepe Ski Centre possa competir com outros destinos internacionalmente. No Centro de Esqui Sarıkamış Cıbıltepe, serviços de saúde de alta qualidade devem ser fornecidos contra possíveis lesões e acidentes dos atletas.

Palavras-chave: Competitividade no Destino; Experiência Turística; Turismo Esportivo, Atletas de Luge, Sarıkamıs.

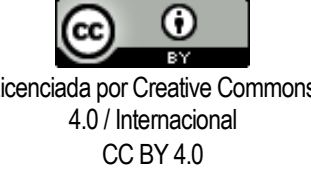

CCBY 4.0

\begin{abstract}
* PhD from the Educational Sciences Institute of Gazi University in the Tourism Management Education (2016). He earned his master's degree in the Department of Tourism Management Education from the Educational Sciences Institute of Gazi University (2005). He received a bachelor degree in Business-Accounting and Trade Education from the Faculty of Trade and Tourism Education of Gazi University (1998). He currently works as a Assistant Professor in the School of llgaz Tourism and Hotel Management at Çankırı Karatekin University. His research skills scholarly activities revolve around three main areas: Sports Tourism, Non Governmental Organizations, and Destination Image. CV: https://akademik.yok.gov.tr/AkademikArama/view/viewAuthor.jsp/ Orcid Id: https://orcid.org/0000-0003-1027-3611 [mkara@karatekin.edu.tr].

** Earned a PhD from the Social Science Institute of Gazi University in the Tourism Management (2019). She received her master's degree in the Department of History of Religions from the Social Sciences Institute of Ankara University (2014). She holded a bachelor degree in Tourist Guide from the School of Tourism and Hotel Management of Erciyes University (2009). She attended a Creativity and Innovation in Tourism training as part of the Erasmus Staff Mobility Programme at Kodolanyi Janos University during the period 02-06 December 2019 in Hungary, Budapest. She continues her academic career at Çankırı Karatekin University, School of llgaz Tourism and Hotel Management, Department of Tourism Management. She does research in fields of Destination Marketing, Tangible Cultural Heritage Tourism and Creative Infusion. CV: https://akademik.yok.gov.tr/AkademikArama/view/viewAuthor.jsp Orcid ld: https://orcid.org/0000-0002-5342-4734 [ sinemkunt@karatekin.edu.tr].
\end{abstract}




\section{EL ANÁLISIS DE LA COMPETITIVIDAD DEL DESTINO SARIKAMIŞ DESDE LA PERSPECTIVA DE LOS ATLETAS DE LUGE: LA RELACIÓN ENTRE LA EXPERIENCIA TURÍSTICA Y LA COMPETITIVIDAD PERCIBIDA DEL DESTINO}

El propósito de esta investigación es examinar la competitividad del destino Sarkamıs desde la perspectiva de los attetas con licencia que participan en la competencia del Campeonato Interclub Natural Luge Turkey 2019. La investigación también pretende revelar la relación entre la competitividad percibida del destino y la experiencia turística. Dos preguntas de investigación fueron abordadas en esta investigación. La primera pregunta era examinar en qué medida la competitividad del destino Sarikamis desde la perspectiva de los atletas luge. La segunda pregunta fue revelar la relación entre la experiencia turística y la competitividad percibida del destino. Los atletas de Luge tienen la oportunidad de adquirir experiencia en una amplia gama de centros de esquí en el área nacional o internacional. Por lo tanto, las perspectivas de los atletas experimentados son importantes para determinar los elementos de ventaja competitiva del destino Sarikamis. La recopilación de datos de esta investigación es el cuestionario realizado con los atletas luge que participan en la competencia $(n=191)$. Los resultados indicaron la competitividad del destino Sarikamis desde la perspectiva de los atletas luge de que las tres puntuaciones medias más altas fueron "La imagen favorable general del destino en la comunidad mundial," El compromiso del destino de promover una imagen positiva "y esto fue lo siguiente:" El compromiso del destino con proporcionando un ambiente seguro y protegido. La investigación también reveló que la percepción de los atletas luge de la competitividad del destino y la experiencia turística en el destino se relacionan positivamente entre sí. La investigación proporcionó implicaciones gerenciales a los gerentes de destino y comercializadores de Sarıkamış con base en los resultados de la investigación. Deben realizarse estudios de imagen eficaces para garantizar que el centro de esquí Sarıkamış Cıbıltepe pueda competir con otros destinos a nivel internacional. En el centro de esquí Sarıkamış Cıbıltepe, se deben proporcionar servicios de salud de alta calidad contra las posibles lesiones y accidentes de los atletas.

Palabras clave: Competitividad del destino; Experiencia turística; Turismo deportivo; Atletas de Luge; Sarıkamıs.

\section{INTRODUCTION}

Tourism development and policies is to provide a competitive tourism product and service that will meet the demand, needs and expectations of tourists to attract tourists and increase tourism revenues. In this respect, various researches about the topic are carried out to protect the environment for future generations, to contribute to the national economy and to improve the quality of life of citizens (Dwyer \& Kim, 2003; Porter, 1990; Ritchie \& Crouch, 2003).

Tourism growth and competition require effective management and marketing strategies (Gruber, Öztüren \& Güneren, 2018) for destinations that are an essential part of the tourism system (Khin, Daengbuppha and Nonsiri, 2014; Xu \& Chan, 2010).

In the global marketplace where competitiveness is increasing, how the destinations are created, protected, sustained and how to strengthen their competitive position is a priority and difficult issue of the tourism industry. This difficulty arises from the complex and multifaceted structure of the tourism industry (Ritchie \& Crouch, 2003).

Nowadays, tourism industry is changing to meet new demands as tourists' demands, needs and expectations change. These changes affect the competitive position of destinations is being makes it important to examination the competitiveness to meet the short and long term goals.

Buhalis (2000) states that success in tourism is related to competitiveness of destinations. For this reason, much research is being done in the literature on the subject of destination competitiveness (Buhalis, 2000; Cracolici, Nijkamp \& Rietveld, 2008; Dwyer \& Kim, 2003; Ekin, 2004; Hallmann, Müller, Feiler, Breuer, \& Roth, 2012; d'Hauteserre, 2000; Kozak \& Rimmington, 1999; Khin, Daengbuppha \& Nonsiri, 2014; Meng, 2006; Przybyszewski, Fernandes \& Niada, 2017; Ritchie \& Crouch, 2003; Sarı Çallı, 2015; Yüncü, 2010).

Many of these researches have approached the issue in terms of supply (Cracolici, Nijkamp \& Rietveld, 2008; Dwyer \& Kim, 2003; Hallmann, Müller, Feiler, Breuer, \& Roth, 2012; d'Hauteserre, 2000; Yoon, 2002). On the other hand, most studies have suggested that the competitive advantage of its destination is closely related to the experience offered, in other words, the tourist experience provided by the destination (Crouch \& Ritchie 2000; Dwyer \& Kim, 2003; Hassan, 2000; Meng, 2006; Ritchie \& Crouch, 2003).

It is necessary to understand the tourist experience (Alcaraz, Palafox-Munoz \& Macias-Ramirez, 2020) to improve the performance of destination products (Karakuş, 2019) and services and to develop destination strategies (Dwyer \& Kim, 2003; Meng, 2006). Demand-side approaches (tourist perspective) seems to be necessary in order to better analyze the competitiveness of the destination.

The motivations of that make up the demand side of tourism are push factors (Dann, 1981), (longings for rest, recreation, adventure, escape and a desire to get away from it all, etc.) and pull factors (service quality, prices and infrastructure, etc.) are another remarkable consideration in terms of destination competition 
(Baloglu \& Uysal, 1996; Yousaf, Amin, Santos and Antonio, 2018).

From this point of view, the correct understanding of tourism demand is crucial in the competitiveness of destinations. As a result of the analysis of tourism demand, destination managers increase destination competitiveness with activities such as destination positioning (Evren \& Kozak, 2018; Pike \& Ryan, 2004), tourist product diversification (Benur \& Bramwell, 2015; Hacıoğlu, N. \& Avcıkurt, 2011) and differentiation (Duman \& Kozak, 2010; Andrades-Caldito, SánchezRivero \& Pulido-Fernández, 2013).

For this reason, the study aims to analyze the relationship of the tourism experience with the perceived destination competitiveness. In this context, winter tourism, which is the subject of the research, is directly related to sports tourism. Sports tourism is examined under three main headings: active sports tourism, event sports tourism and nostalgia sports tourism. Within the scope of active sports tourism, tourists participating in sports activities, tourists who do sports during the holidays and athletes participating in sporting competitions are evaluated.

In the context of event sports tourism, viewers of sports competitions can be evaluated, and in the context of nostalgia sports tourism, visitors to sports museums or places where sports competitions, championships and Olympics take place can be evaluated (Gibson, 1998, 2004; Kurtzman, 2005; Van Rheenen, Cernaianu \& Sobry, 2013). Winter tourism generally includes active sports tourism and event sports tourism activities.

The luge athletes involved in the research have the experience of being involved in competitions in different winter tourism destinations within the framework of active sports tourism and therefore it is possible to compare facilities in different destinations in terms of their performance and service quality.

The examination of the competitiveness of the destination from the perspective of athletes increases the importance of the research. As a result, this study is based on analyzing destination competitiveness from the perspective of the luge athletes.

\section{THEORETICAL FRAMEWORK}

The growth and competition in tourism aroused great interest in highly effective marketing and management strategies for the tourism destination and made competitiveness a critical emphasis in today's changing market (Meng, 2006). Therefore, a great number of studies are carried out on destination competitiveness.

Despite extensive literature on competitiveness, researchers have shown that this is not a clear and widely understood definition due to its complexity. Even the definition of the World Competitiveness Yearbook has varied to some extent over the years (Dwyer \& Kim, 2003). However, some authors try to define competitiveness from a macro and micro perspective. For example, Ritchie and Crouch (2003) discussed destination competitiveness mainly on the industry level which could be considered as a macro-level perspective.

Competitiveness, in this case, is a very broad construct engaging all social, cultural, and economic aspects which may influence the performance of a nation in international markets (Porter, 1990; Dwyer and Kim, 2003). Conversely, from a micro perspective, competitiveness refers to the organization's ability to stay in the business and maintain sustained growth and development in financial terms (Prahalad \& Hamel, 1990).

Although there are different definitions and perspectives on competitiveness in the literature, the importance of competitiveness for destination cannot be denied. The competitiveness of the destinations increases the quality of life of the citizens living in that destination, contributes to the protection of the environment for future generations and provides many benefits such as helping to increase tourism revenues by providing a satisfactory and unforgettable experience to tourists (Crouch, 2003).

Competitiveness also extends the lifespan of destinations by providing the ability to protect and develop the market position and share of the destination over time (d'Hartserr, 2000).

The destination can be seen as a supplier that provides the necessary tourist products and services required to have a better or at least equal experience than the past experience of the tourist who is the consumer by managing and marketing its attractions effectively and efficiently (Damian, 2017).

Dwyer and Kim (2003) have defined the competitiveness of the destination as the ability of the destination to perform better than the other destinations, while providing the products and services that are considered important by tourists. They emphasized experience in defining destination competitiveness Therefore, the experience of a tourist can be used to measure the competitiveness of the destination (Cracolici, Ninjkamp \& Rietveld, 2008; Kong \& Chang, 2016).

Tourism researchers have been working on how to comprehend and measure destination competitiveness from the early 1990s to the present. Since then, the number of studies that have been trying to develop a theoretical and conceptual basis has increased significantly (Decasper, 2015).

First of all, studies were carried out to determine the factors of the competitiveness of destination and then the effect levels of these factors on the 
competitiveness were determined (Buhalis, 2000; Cracolici, Ninjkamp and Rietveld, 2008; Crouch \& Ritchie, 2003; d'Hauteserre, 2000; Dwyer \& Kim, 2003). In addition to this, despite the literature expansion related to the competitiveness of the destination, the studies made with the perspective of demand in other words it is tourist gaze are limited (Meng, 2006).

This situation also validates the national studies in Turkey. As a result of the examination conducted in the national research center database of the Higher Education Council, very few studies have been encountered that examined the demand side competitiveness of destination (Ekin, 2004; Yüncü, 2010 Sarı Çallı, 2015).

However, any study examining the relationship between destination competitiveness and experience in terms of national the licensed athletes could not be reached. They have the opportunity to get experience in a wide range at national or international destination.

It is thought that the perspectives of experienced athletes are important in determining the competitive advantage elements of destination. It was concluded that the subject should be examined. Based on this, it is aimed to contribute to the literature with the research findings.

\section{METHODOLOGY}

To address the research problems, it was necessary to unravel the relationship between tourism experience and destination competitiveness. Two research questions were addressed in this research.

The first question was to examine to what extent the competitiveness of Sarikamis destination from the luge athletes' perspective.

The second question was to reveal the relationship between the tourism experience and perceived destination competitiveness.

To find out the answer the questions of the research, an extensive review of the existing literature has been conducted, and a theoretical model is developed to explore the relationship between perceived destination competitiveness and tourism experience (Figure 1).

\section{Tourism experience \\ perceived destination competitiveness}

Figure 1: Proposed tourism experience and perceived destination competitiveness model. Source: proper elaboration.

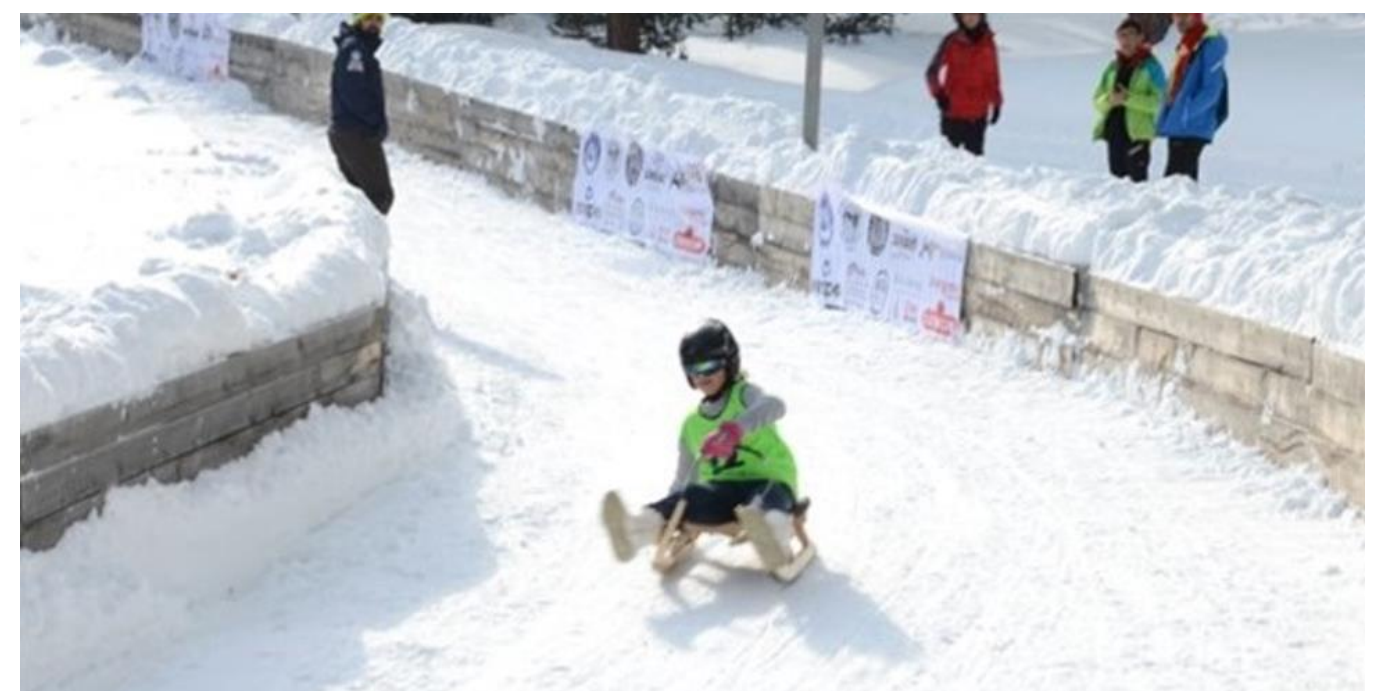

Figure 2: luge athletes participating in 2019 Interclub Natural Luge Turkey Championship competition. Source: The Luge Federation of Turkey (2019).

Sarıkamış Ski Center (Map 1) is one of the Turkey's most important five winter sports and winter tourism center (Ministry of Culture and Tourism, 2019). In this context, Cibiltepe Ski Center Sarıkamış district of Kars was chosen as the study location among the leading ski resorts in Turkey.
The important advantages of Sarikamis destination that distinguishes it from the other competitors are the snow reliability, snow quality, and slope conditions (Evren \& Kozak, 2018). Very convenient for skiing and only Alps in the world powder crystal snow is also available in Cibıltepe Ski Center, 
Sarıkamış (Governorship Kars, 2019). Therefore, it becomes important to examination of Sarikamis Destination Competitiveness.

The population of the research is the luge athletes participating in 2019 Interclub Natural Luge Turkey Championship competition (Figure 2). The Luge athletes have the opportunity to get experience in a wide range of ski centers at national or international area. Therefore, the perspectives of experienced athletes are important in determining the competitive advantage elements of any destination.

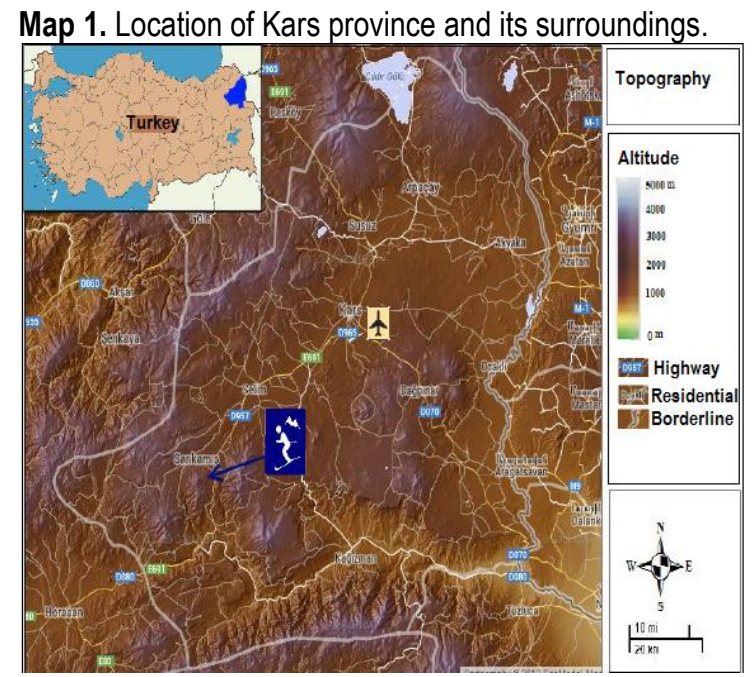

Source: Demir (2015).

The sampling frame for this research includes the licensed luge athletes participating the Interclub Natural Luge Turkey Championship competition in Sarıkamış, and they are 18 years of age or older. A total of 220 the luge athletes participated in the competition (Serhat Development Agency, 2019).

Before the competition, a runway trial was performed with all licensed athletes, and four separate meetings were held between 28.02.2019 and 03.03.2019 for each category to get their thoughts on the track. The research instrument was a structured questionnaire implemented through face to face interviews at the end of each meeting.

The data were collected between 28.02.201903.03.2019 $(n=191)$. The data collection of this research was the questionnaire and at the meeting out, a total of 220 questionnaires were distributed to reach all of sample population.

The language of questionnaire was Turkish the mother tongue of the athletes. In order to ensure the validity and reliability of the questionnaire used in the research, the questionnaire was translated into Turkish by two tourism academicians. After the translation of the questionnaire in both languages (English and Turkish) it was decided that it was appropriate to use for the research.
In the study, two scales were used: tourism experience and perceived competitiveness. The tourism experience scale was first put forward by Meng (2006) on the scale of tourist experience developed by Clawson and Knetsch (1966), developed by Killion (1992) and Craig-Smith and French (1994).

In order to measure the competitiveness of the perceived destination, it was preferred to use the scale developed by Meng (2006) based on Ritchie and Crouch (2003) model.

For each scale used in the study, reliability analyses are applied. When Table 1 is examined, at first, reliability test analysis are applied to 28 statements, which are included into the "Tourism Experience" scale and Cronbach Alpha co-efficiency is determined as 0,955.

After that, as consequence of reliability analysis of 22 statements included into the "Perceived Competitiveness", Cronbach Alpha coefficient is determined as 0,946 and it is possible to say that applied scales are at high reliability level. It is stated that; while Alpha coefficient is expected as at least 0,5 in social sciences, scales which reveals 0,7 and higher results have high reliability (Coşkun et al., 2015, p. 126).

Hence Cronbach Alpha coefficient of the overall scale is determined as 0,970 , it is possible to state that all of the scales as a whole provide reliability requirement and therefore they are applicable for statistical analysis.

Table 1: Reliability Analysis Results of The Research Scales.

\begin{tabular}{|l|l|l|}
\hline Scale & $\begin{array}{l}\text { Number of } \\
\text { Statements }\end{array}$ & $\begin{array}{l}\text { Cronbach } \\
\text { Alpha }\end{array}$ \\
\hline $\begin{array}{l}\text { Tourism } \\
\text { experience scale }\end{array}$ & 28 & 0,955 \\
\hline $\begin{array}{l}\text { Perceived } \\
\text { competitiveness } \\
\text { scale }\end{array}$ & 22 & 0,946 \\
\hline Overall & 50 & 0,970 \\
\hline
\end{tabular}

Source: proper elaboration.

\section{RESULTS AND DISCUSSION}

The whole sample was composed of 191 participant (47,6\% female and $52,4 \%$ male). The ratio of male and female seem almost equal. With respect to age $97 \% 18$ years or older, $61,3 \%$ of the sample had undergraduate or graduate.

Among those who estimated their yearly income in Turkish Lira the mode was $€ 1,501-2,500$. Of those with someone else, $83,2 \%$ were student and $91,6 \%$ not married. All participants were licensed athletes. 


\subsection{The Results of the Mean Scores, Standard Deviation, Kurtosis and Skewness of Perceived Destination Competitiveness}

Participants were asked for the destination competitiveness of Sarıkamış based on a scale between 1 to 5 (1 representing "Not At All Important" and 5 "Very Important"). Mean test was conducted which illustrated significant mean scores.

The first question was to examine to what extent the competitiveness of Sarikamis destination from the luge athletes' perspective. When Table 2 was analyzed, the results indicated that the highest three mean scores were "The destination's overall favorable image in the world community $(M=3,34)$, "The destination's commitment to promoting a positive image $(M=3,33)$ ", and this was following: "The destination's commitment to providing a safe and secure environment $(M=3,29)$ ".
When the value ranges are taken into consideration, the average of the above items is "neither/nor important" (Kaplanoğlu, 2014). It was seen that the luge athletes were undecided about the competitive power of Sarıkamış.

On the other hand, the averages of the above items were found to be close to each other. It is clear that three items supporting each other come to the forefront in destination competitiveness.

In a competitive industry such as tourism, image is undoubtedly one of the important marketing elements that distinguish destinations from competitors (UNWTO, 2017).

Destinations use image elements extensively in order to be distinguished from their competitors and to be different (Edgell, Ruf \& Agarwal, 2000). In this study, it has been seen that the image element comes to the forefront in destination competitiveness.

Table 2: Items of the Constructs with Mean Scores and Standard Deviation of Perceived Destination Competitiveness.

\begin{tabular}{|l|l|l|l|l|l|}
\hline Variables & $\mathbf{N}$ & Mean & SD & Kurt. & Skew. \\
\hline The destination's overall favorable image in the world community & 191 & 3,34 & 1,12 &,- 71 &,- 25 \\
\hline The destination's commitment to promoting a positive image & 191 & 3,33 & 1,15 &,- 74 &,- 27 \\
\hline The destination's commitment to providing a safe and secure environment & 191 & 3,29 & 1,22 & $-1,03$ &,- 09 \\
\hline $\begin{array}{l}\text { The destination's continuous commitment to the ongoing improvement and } \\
\text { development of a high-quality destination }\end{array}$ & 191 & 3,26 & 1,10 &,- 69 &,- 14 \\
\hline The destination's alliance/connection with intermediates in the tourism sector & 191 & 3,26 & 1,17 &,- 69 &,- 30 \\
\hline A good value for the money spent for the vacation experience & 191 & 3,25 & 1,19 & $-1,04$ &,- 10 \\
\hline The overall destination experience offered "fits" the needs of visitors & 191 & 3,24 & 1,21 &,- 96 &,- 05 \\
\hline $\begin{array}{l}\text { The nature of the destination's setting helps visitors to function comfortably in } \\
\text { daily activities }\end{array}$ & 191 & 3,24 & 1,20 &,- 84 &,- 24 \\
\hline The destination's commitment to providing a satisfactory vacation experience & 191 & 3,24 & 1,09 &,- 65 &,- 20 \\
\hline Competitive price for the overall vacation relative to competitor destinations & 191 & 3,22 & 1,18 &,- 91 &,- 11 \\
\hline High quality of services/amenities at the destination & 191 & 3,19 & 1,12 &,- 83 &,- 10 \\
\hline Problem-free vacation arrangements with the destination & 191 & 3,17 & 1,16 &,- 94 &,- 18 \\
\hline Unique tourism resources & 191 & 3,17 & 1,13 &,- 81 &,- 07 \\
\hline High quality tourism infrastructure & 191 & 3,15 & 1,17 &,- 95 &,- 03 \\
\hline Friendliness and hospitality of the local people & 191 & 3,15 & 1,21 & $-1,02$ &,- 13 \\
\hline Favorable weather/climate at the destination & 191 & 3,14 & 1,15 &,- 84 &,- 20 \\
\hline The destination's commitment to preserving the destination environment & 191 & 3,14 & 1,19 &,- 95 &,- 06 \\
\hline Policies/regulations favorable to tourists & 191 & 3,10 & 1,13 &,- 82 &,- 12 \\
\hline A good variety of activities offered for visitors & 191 & 3,06 & 1,19 &,- 86 &,- 22 \\
\hline Smooth travel to the destination and back home & 191 & 3,00 & 1,13 & $-1,03$ &, 05 \\
\hline Easy access to meaningful information about the destination before travel & 191 & 2,96 & 1,13 &,- 88 &,- 03 \\
\hline Easy access to the destination & 191 & 2,50 & 1,39 & $-1,35$ &, 33 \\
\hline
\end{tabular}

Source: proper elaboration from the empirical data.

On the other hand, the last three mean scores from the perspectives of the luge athletes were "Smooth travel to the destination and back home $(M=3,00)$ ", "Easy access to meaningful information about the destination before travel $(M=2,96)$ ", and "easy access to the destination ( $M=2,50)$ " in destination competitiveness.
Considering the value ranges, the average of the above items is called "not important" (Kaplanoğlu, 2014). These findings show that transportation is not important as a competitive element. The athletes are arriving to destination to participate in the championship competition and therefore this may be the reason for not important of the transportation element. 


\subsection{The Results of the relationship between the tourism experience and perceived destination competitiveness}

In this research the second question was to reveal the relationship between the tourism experience and perceived destination competitiveness. In this context, Pearson correlation analysis was used to test proposed tourism experience and perceived destination competitiveness model (Figure 1).

When Table 3 was analyzed, it was found that there was a significant high relationship between destination competition and tourism experience $(p<, 05)$. According to luge athletes, there is a high positive relationship between their experience in Sarıkamış and their competitiveness perceptions. As the experience of the athletes in Sarıkamış increases, so does their perception of competitiveness.

In tourism literature, a positive relationship between destination competition and tourism experience has been demonstrated in previous studies (Hassan, 2000; Dwyer, Forsyth \& Rao, 2000; Dwyer \& Kim, 2003; Dwyer et al., 2004; Meng, 2006; Cracolici \& Nijkamp, 2008; Crouch, 2011; Manthiou et al., 2014). In this study, a positive relationship was also found between destination competition and tourism experience. It can be said that this information supports the literature.

Table 3: The relationship between the tourism experience and perceived destination competitiveness.

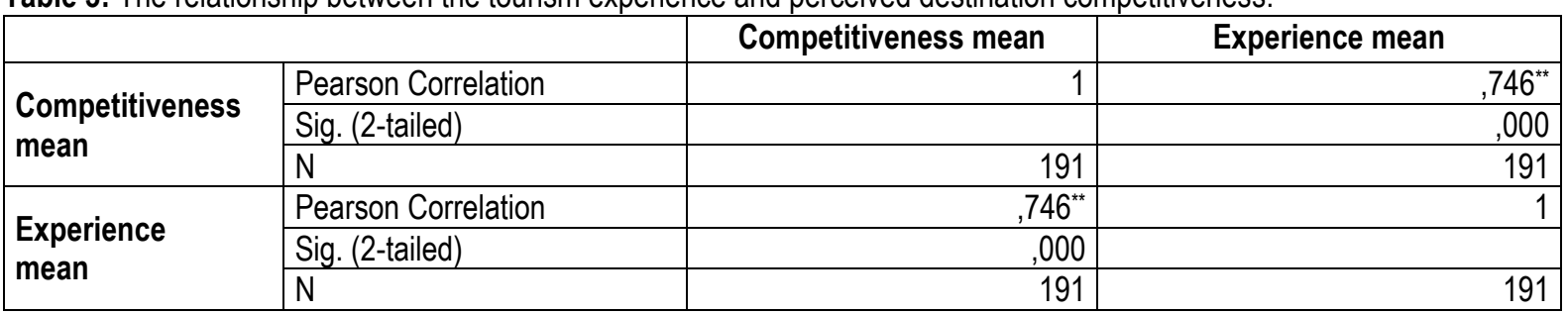

**. Correlation is significant at the 0.01 level (2-tailed)

Source: proper elaboration from the empirical data.

\section{CONCLUSIONS}

Destinations are competing with each other due to the increasing mobility of tourists due to many other reasons, especially globalization and technological developments.

There are several factors affecting destination competitiveness, which can be defined as the ability of the destination to maintain and improve its market position and share over time.

One of these factors is the tourist experience. In today's competitive business environment, it is not enough to prioritize goods and services with their functions.

Therefore, it is necessary to provide them with an "experience" that will distinguish them from their peers. This is also the case for destinations, and it is important to provide a quality experience as well as the features that the destinations have to gain competitiveness.

In the literature, there are studies showing that there is a significant relationship between tourism experience and destination competitiveness (Hassan, 2000; Dwyer, Forsyth \& Rao, 2000; Dwyer \& Kim, 2003; Dwyer et al., 2004; Meng, 2006; Cracolici \& Nijkamp, 2008; Crouch, 2011; Manthiou et al., 2014).

Based on this relationship in the literature, tourism experience and destination competitiveness were examined in this research. Two research questions were addressed in this study.

The first question was to examine to what extent the competitiveness of Sarıkamış destination from the luge athletes' perspective. The second question was to reveal the relationship between the tourism experience and perceived destination competitiveness.

To find out the answer the questions of the research, an extensive review of the existing literature has been conducted, and a theoretical model is developed to explore the relationship between perceived destination competitiveness and tourism experience.

The results indicated for the first research question that the highest three mean scores were "The destination's overall favorable image in the world community, "The destination's commitment to promoting a positive image", and this was following: "The destination's commitment to providing a safe and secure environment".

From the perspective of luge athletes, the image element has come to the forefront in the competitiveness of the Sarıkamıs destination. The luge athletes are undecided about the image of Sarıkamış. Although the image is a result of a complex and long process, it benefits destinations in many ways. However, there is no consensus in the 
literature about image formation, evaluations on perception, knowledge and effectiveness play an important role in image formation (Akyurt and Atay, 2009).

In this context, proactive initiatives should be taken to create an effective image of the Sarıkamış destination. It is important that the destination be a safe place in choosing the destination (Mendoza, 2015), and to take measures against possible accidents and injuries of athletes. The availability of the infrastructure needs to be evaluated before the destinations are created (D'Mello \& Subhash, 2016).

On the other hand, in destination competitiveness for luge athletes the last three mean scores were "Smooth travel to the destination and back home", "Easy access to meaningful information about the destination before travel", and "easy access to the destination". It can be said that athletes do not have high expectations or do not seek great comfort.

The results indicated for the second research question that is a significant relationship between the tourism experience and perceived destination competitiveness in line with the literature.

This study is important in two aspects. First, the competitiveness of Sarıkamış for the first time was evaluated from the perspective of the luge athletes. Second, a significant relationship was found between experience and destination competitiveness and contributed to the literature.

This research has two limitations. First, it has the limitation of not generalizing the results as this is a Sarıkamış-specific study. Second, the results reflect the thoughts of the luge athletes.

Also, managerial implications to Sarıkamış destination managers and marketers based on the research findings:

- Effective image studies should be conducted in order to ensure that the Sarıkamış Cıbıltepe Ski Center can compete with other destinations internationally.

- A safe environment should be provided by local authorities for visitors and athletes at Sarıkamış Cibıltepe Ski Center.

- In the immediate vicinity of Sarıkamış Cıbıltepe Ski Center, there should be shops for personal needs.

- In Sarıkamış Cıbıltepe Ski Center, a faster cable car line and higher quality peak cafes should be established during skiing.

- In Sarıkamış Cıbıltepe Ski Center, high-quality health services should be provided against the possible injuries and accidents of the athletes.

- Various mountain activities should be planned for athletes and visitors by examining examples of international ski centers. For example, Heliski or off-piste tours should be organized.

- Easy access from Sarıkamış Cıbıltepe Ski Center to Sarıkamış or Kars should be provided.

- Since the experience affects the perception of competitiveness, activities should be carried out to enrich the athletes' experiences. For example, the reproduction of entertainment centers and the provision of different services, as usual.

- Satisfaction or performance questionnaires, especially for athletes, can be conducted by the Provincial Directorate of Culture and Tourism and hotel establishments. In line with these questionnaires, necessary arrangements can be made in the region, activities can be planned and deficiencies in facilities can be eliminated.

\section{REFERENCES}

Akyurt, H., ve Atay, L. (2009). Destinasyonda Imaj Oluşturma Süreci. Aksaray Üniversitesi Iktisadi ve Idari Bilimler Fakültesi Dergisi, 1(1), 1-14. https://dergipark.org.tr/tr/pub/aksarayiibd/issue/22558/ 241035.

Alcaraz, J. O. R., Palafox-Muñoz, A., \& Macías-Ramírez, A. (2020). El Marketing Interno para la Experiencia Turística. Revista Latino-Americana De Turismologia.

Andrades-Caldito, L., Sánchez-Rivero, M., \& PulidoFernández, J. I. (2013). Differentiating competitiveness through tourism image assessment: an application to Andalusia (Spain). Journal of Travel Research, 52(1), 68-81. https://doi.org/10.1177/0047287512451135.

Baloglu, S., \& Uysal, M. (1996). Market segments of push and pull motivations: A canonical correlation approach. International Journal of Contemporary Hospitality Management, 8(3), 3238. https://doi.org/10.1108/09596119610115989.

Benur, A. M., \& Bramwell, B. (2015). Tourism product development and product diversification in destinations. Tourism Management, 50, 213-224. https://doi.org/10.1016/j.tourman.2015.02.005.

Buhalis, D. (2000). Marketing the competitive destination of the future. Tourism Management, 21(1), 97-116. https://doi.org/10.1016/S0261-5177(99)00095-3.

Chambers, L. 2010. Destination competitiveness: An Analysis of the characteristics to differentiate allinclusive hotels \& island destinations in the Caribbean (Thesis - PhD). Rochester Institute of Technology. https://scholarworks.rit.edu/cgi/viewcontent.cgi?article $=1474 \&$ context=theses.

Cracolici, M. F., Nijkamp, P., \& Rietveld, P. (2008). Assessment of tourism competitiveness by analyzing destination efficiency. Tourism Economics, 14(2), 325342. https://doi.org/10.5367/000000008784460427.

Craig-Smith, S., \& French, C. (1994). Learning to live with tourism. Melbourne: Pitman. 
https://www.cabdirect.org/cabdirect/abstract/1995180 2572.

Crouch, G. I., \& Ritchie, J. B. (2000). The competitive destination: A sustainability perspective. Tourism Management, 21(1), doi: $10.1079 / 9780851996646.0000$

Clawson, M., \& Knetsch, J.L. (1966). Economics of Outdoor Recreation: Resources for the Future. Baltimore: John Hopkins.

Coşkun, R., Altunışık, R., Bayraktaroğlu, S., \& Yıldııım, E. (2015). Sosyal bilimlerde araştırma yöntemleri spss uygulamalı. Sakarya: Sakarya Yayıncılık.

Crouch, G. I. (2011). Destination competitiveness: An analysis of determinant attributes. Journal of Travel Research, 50(1),

$27-45$. https://doi.org/10.1177/0047287510362776.

Damian, A. G. (2017). Transformaciones Espaciotemporales Inducidas por las TIC en la Experiencia Turística, Reflexiones Desde el Construccionismo Social. Revista Anais Brasileiros de Estudos Turísticos-ABET, 23-34.

Dann, G. M. (1981). Tourist Motivation An Appraisal. Annals of Tourism Research, 8(2), 187-219. https://doi.org/10.1016/0160-7383(81)90082-7.

Decasper, S. M. (2015). Competitividad y Desarrollo Sostenible en el Turismo. Revista Anais Brasileiros de Estudos Turísticos-ABET, 47-58.

Demir, M. (2015). Kars Illinin Nüfus Gelişimi ve Başlıca Demografik Özellikleri. Doğu Coğrafya Dergisi, 20(34), 127-156.

Duman, T., \& Kozak, M. (2010). The Turkish tourism product: Differentiation and competitiveness. Anatolia: An International Journal of Tourism and Hospitality Research, 21(1), 89-106. https://doi.org/10.1080/13032917.2010.9687092.

Dwyer, L., Forsyth, P., \& Rao, P. (2000). The price competitiveness of travel and tourism: a comparison of 19 destinations. Tourism Management, 21(1), 9-22. https://doi.org/10.1016/S0261-5177(99)00081-3.

Dwyer, L., \& Kim, C. (2003). Destination competitiveness: determinants and indicators. Current Issues in Tourism, 6(5), 369-414. https://doi.org/10.1080/13683500308667962.

Dwyer, L., Mellor, R., Livaic, Z., Edwards, D., \& Kim, C. (2004). Attributes of destination competitiveness: A factor analysis. Tourism Analysis, 9(1-2), 91-101. https://doi.org/10.3727/1083542041437558.

d'Hauteserre, A. M. (2000). Lessons in managed destination competitiveness: the case of Foxwoods Casino Resort. Tourism Management, 21(1), 23-32. https://doi.org/10.1016/S0261-5177(99)00097-7.

Edgell, D. L., Ruf, K. M., and Agarwal, A. (2000). "Strategic Marketing Planning for the Tourism Industry". Journal of Travel ve Tourism Marketing, 8(3), 111-120. https://doi.org/10.1300/J073v08n03_08.

Ekin, Y. (2004). Turizm Paydaşları Perspektifinden Turizm Gelişimi ve Destinasyon Rekabetçiliği: Antalya Örneği. Yüksek Lisans Tezi, Akdeniz Üniversitesi Sosyal Bilimler Enstitüsü, Antalya.

Evren, S., \& Kozak, N. (2018). Competitive positioning of winter tourism destinations: A comparative analysis of demand and supply sides perspectives-Cases from Turkey. Journal of Destination Marketing and Management, $\quad$ 9(January), 247-257. https://doi.org/10.1016/j.jdmm.2018.01.009.

Gibson, H. J. (1998). Active sport tourism: Who participates? Leisure Studies, 17(2), 155-170. https://doi.org/10.1080/026143698375213.

Gibson, H. J. (2004). Moving beyond the "what is and who" of sport tourism to understanding "why." Journal of Sport and Tourism, 9(3), 247-265. https://doi.org/10.1080/1477508042000320232.

Governorship Kars (2019). Retrieved from http://www.kars.gov.tr/sehirkartlarikayakmerkezi (08.03.2019).

Gruber, T., Öztüren, A., \& Özdemir, E. G. (2018). Product Improvement as a Tool for Competition in Austrian Ski Schools: The Case of Ski School Toni Gruber. Journal of Multidisciplinary Academic Tourism, 3(2), 1-9. https://doi.org/10.31822/jomat.469586.

Hacıoğlu, N. \& Avcıkurt, C. (2011). Turistik Ürün Çeşitlendirmesi (2nd ed.). Ankara: Nobel Yayın Dağıtım.

Hallmann, K., Müller, S., Feiler, S., Breuer, C., \& Roth, R. (2012) 'Suppliers' perception of destination competitiveness in a winter sport resort", Tourism Review, 67(2), 13-21. https://doi.org/10.1108/16605371211236105.

Hassan, S. S. (2000). Determinants of market competitiveness in an environmentally sustainable tourism industry. Journal of Travel Research, 38(3), 239-245. https://doi.org/10.1177/004728750003800305.

Kaplanoğlu, E. (2014). The Basic Causes And Potential Consequences of Occupational Stress: A Study Of Certified Public Accountants In Manisa Province. Journal of Accounting \& Finance, (64). https://dergipark.org.tr/tr/download/article-file/427553.

Karakuş, Y. (2019). Identifying the Best Alternative Tourism Product for a Destination: the case of Cappadocia. Revista Anais Brasileiros de Estudos Turísticos-ABET, 9, 1-9.

Khin, E., Daengbuppha, J., \& Nonsiri, P. (2014). Destination competitiveness: a structural model for measuring attributes competitiveness of Bagan, Myanmar. International Journal of Business, Economics and Law, 4(2), 51-59. http://ijbel.com/wpcontent/uploads/2014/06/KLE4221-Ei-Ei-KhinPetchsri-Nonsiri-DESTINATIONCOMPETITIVENESS.pdf.

The Luge Federation of Turkey (2019). Retrieved from kizak.gov.tr (19.05.2019).

Killion, G. L. (1992). Understanding Tourism. Rockhampton: Central Queensland University.

Kong, W. H., \& Chang, T. Z. (2016). Souvenir shopping, tourist motivation, and travel experience. Journal of Quality Assurance in Hospitality \& Tourism, 17(2), 163177. https://doi.org/10.1080/1528008X.2015.1115242.

Kozak, M., \& Rimmington, M. (1999). Measuring tourist destination competitiveness: conceptual considerations and empirical findings. International 
Journal of Hospitality Management, 18(3), 273-283. https://doi.org/10.1016/S0278-4319(99)00034-1.

Kurtzman, J. (2005). Sports tourism categories. Journal of Sport Tourism, 10(1), 15-20. https://doi.org/10.1080/14775080500101502.

Manthiou, A., Lee, S., Tang, L., \& Chiang, L. (2014). The experience economy approach to festival marketing: Vivid memory and attendee loyalty. Journal of Services Marketing, 28(1), 22-35. https://doi.org/10.1108/JSM06-2012-0105.

Mendoza, V. V. S. (2015). Escenarios turísticos e inseguridad en el turismo. Revista Latino-Americana de Turismologia, 1(1), 61-74. file:///C:/Users/user/Downloads/9965Texto\%20do\%20artigo-45002-3-10-20151216.pdf.

Meng, F. (2006). An examination of destination competitiveness from the tourists' perspective: the relationship between quality of tourism experience and perceived destination competitiveness (Doctoral dissertation, Virginia Tech).

Ministry of Culture and Tourism (2019). Retrieved from http://www.karskulturturizm.gov.tr/ (08.03.2019).

Pike, S., \& Ryan, C. (2004). Destination positioning analysis through a comparison of cognitive, affective, and conative perceptions. Journal of Travel Research, 42(4), 333-342. https://doi.org/10.1177/0047287504263029.

Porter, M. E. (March-April, 1990). The Competitive Advantage of Nations. Harvard Business Review, 68(2), 74-91. http://www.economie.ens.fr/IMG/pdf/porter_1990_the_competitive_advantage_of_nations.pdf.

Prahalad, C. H. \& Hamel, G. (May-June, 1990). The core competence of the corporation. Harvard Business Review, 68(3), 295-336. https://hbr.org/1990/05/thecore-competence-of-the-corporation.

Przybyszewski, J., Fernandes, P. O., \& Niada, A. C. M. (2017). A competitividade turística entre as regiões brasileiras. Anais Brasileiros de Estudos Turísticos-
ABET, 65-81. https://doi.org/10.34019/22382925.2017.v7.3173.

Ritchie, J. B., \& Crouch, G. I. (2003). The competitive destination: A sustainable tourism perspective. Cabi.

Sarı Çallı, D. (2015). Destinasyon Rekabet Gücü Açısından İstanbul'un Karşılaştırmalı Analizi. Doktora Tezi, Sakarya Üniversitesi Sosyal Bilimler Enstitüsü, Sakarya.

Serhat Development Agency, (2019). Retrieved from https://www.serka.gov.tr/haberler/sarikamis-kizakyarismasina-ev-sahipligi-yapti (08.03.2019).

The Luge Federation of Turkey (2019). Retrieved from kızak.gov.tr (19.05.2019).

Van Rheenen, D., Cernaianu, S., \& Sobry, C. (2017). Defining sport tourism: A content analysis of an evolving epistemology. Journal of Sport \& Tourism, 21(2), 75-93. https://doi.org/10.1080/14775085.2016.1229212.

World Tourism Organization (UNWTO). (2018). Retrieved from: http://marketintelligence.unwto.org/content/conceptual -framework-0 (20.02.2018).

Xu, J. B., \& Chan, S. (2016). A new nature-based tourism motivation model: Testing the moderating effects of the push motivation. Tourism Management Perspectives, 18, 107-110. https://doi.org/10.1016/j.tmp.2016.01.001.

Yoon, Y. (2002). Development of a structural model for tourism destination competitiveness from stakeholders' perspectives (Doctoral dissertation, Virginia Tech).

Yousaf, A., Amin, I., Santos, C., \& Antonio, J. (2018). Tourist's motivations to travel: A theoretical perspective on the existing literature. Tourism and Hospitality Management, 24(1), 197-211. https://doi.org/10.20867/thm.24.1.8.

Yüncü, H.R. (2010). Development of A Structural Model For Wine Tourism Destination Competitiveness: Case of Cappadocia (Doctoral dissertation) Anadolu University, Eskişehir. 